\title{
Does Nutrition Really Matter for the Productivity of Smallholder Farmers?
}

\author{
Azra Tilai ${ }^{1 *}$, Rayenda Khresna Brahmana ${ }^{1}$ and Hui Wei You ${ }^{2}$ \\ ${ }^{1}$ Faculty of Economics and Business, Universiti Malaysia Sarawak, 94300 Kota Samarahan, Sarawak, Malaysia \\ ${ }^{2}$ School of Management, Zhejiang University, 866 Yuhangtang Rd, Xihu, Hangzhou, Zhejiang, 310027, China
}

\begin{abstract}
Household-level data from Malaysia Smallholder paddy farmers are used to test whether higher caloric intake enhances family farm labour productivity. This study contests the notion behind the efficiency wages hypothesis. Farmers' productivity is estimated using Data Envelopment Analysis. To avoid estimation bias from reverse causality, we utilize a two-stage least square approach by choosing prices, household demography, and farm assets as instrumental variables. The results show that high caloric intake significantly affects farmers' productivity in a non-linear relationship. Farmers with obesity and overweight conditions produce less per unit of inputs and supply more labour than farmers with normal BMI and normal weight. The model results show that production inefficiency increases significantly with the high consumption calories, high BMI, and obesity of farmers providing solid support for the nutrition-productivity hypothesis. The marginal effect on productivity falls drastically as caloric intake increases. These outcomes recommend that investing in the health sector in rural areas will improve farmer productivity. Policymakers should develop approaches that will maximize agricultural investments' contribution to agricultural productivity and the overall rural economy.
\end{abstract}

Keywords: Agricultural, farmers, health status, nutrition, productivity

\author{
ARTICLE INFO \\ Article history: \\ Received: 15 November 2020 \\ Accepted: 16 April 2021 \\ Published: 30 June 2021 \\ DOI: https://doi.org/10.47836/pjssh.29.2.21 \\ $\overline{\text { E-mail addresses: }}$ \\ azratilai@yahoo.com (Azra Tilai) \\ brkhresna@unimas.my (Rayenda Khresna Brahmana) \\ feiyu92you@hotmail.com (Hui Wei You) \\ * Corresponding author
}

\section{INTRODUCTION}

In the health economics literature, food intake is an important determinant of work effort per unit time or units of labour efficiency. Previous empirical findings explain that poor food intake leads to poor well-being (Owen \& Corfe, 2017) or low productivity (Strauss, 1986; Ulimwengu, 
2009). An undernourished household will face issues in decreasing body strength and lower resistance to infections (Chandra, 1992; Efthimiou et al., 1988; Millward, 2017; Sullivan et al., 1990), weight loss, and muscle wasting (Badi \& Ba-Saddik, 2016; Bunker et al., 1987; Castaneda et al., 1995; Gersovitz et al., 1982), mortality (Payette et al., 2002; Myrskylä \& Chang, 2009), and longer periods of illness and hospitalisation (Weiss et al., 2016).

Unfortunately, a large proportion of the undernourished are smallholder farmers (Chiputwa \& Qaim, 2016; FAO, 2014), and farmers arguably will have low productivity due to this poor nutrition situation (i.e., Popkin, 1978; Quaye, 2008; Strauss, 1986) as farming requires a lot of labour (Euler et al., 2017). The heavy labour activities in farming can create high energy demands that cannot be met from limited access to nutritious food (Wiggins \& Keats, 2013). In a light, malnourished farmers theoretically have low productivity due to their nutritional status.

Conversely, recent studies argue a positive relationship between nutrition and productivity (i.e., Fanzo, 2017; Powell et al., 2015; Sibhatu \& Qaim, 2018; Sibhatu et al., 2015). Sibhatu and Qaim (2018), for example, argue that further diversifying small-farm production would be a good strategy to improve nutrition. Fanzo (2017) provides evidence that both market-based solutions or diverse production strategies are better for diets. Rising food prices force low-income households to save their money and ignore healthy nutritional intake benefits (Lo et al., 2009). Households experiencing poverty consistently have poorer nutritional outcomes than wealthier members of their society (Dowler \& Dobson, 1997). Consequently, high-calorie intake does not mean having good health (i.e., Robinson et al., 2013). Higher calorie intake puts smallholder farmers into a complex health situation, where they may trap into obesity case; a factor that reduces productivity.

This nutrition-productivity issue is exacerbated by the fact that healthy food is expensive, and bad food is cheap (Darmon \& Maillot, 2010). Smallholder farmers most likely living in poor conditions, eat unhealthy food leading to obesity (Little et al., 2016). This differs from prior findings before 2010, such as Aromolaran (2004), whereas more calorie intake, better productivity. In today's research context, higher calorie intake worsens farmers' productivity due to their nutritional value. As a result, a farmworker who has been inadequately nourished all his life may have poor health and not be very productive ( $\mathrm{Hu}$ \& Wang, 2019). Intriguingly, smallholder paddy farmers play a significant role as food producers in developing countries such as Malaysia (Fahmi et al., 2013). Considering the importance of these paddy farmers, this study re-examines the relationship between nutrition status and productivity of paddy farmers in Malaysia. Apart from it, we argue that the nutrition-productivity hypothesis may have different results with a farmer's health condition. For obese and overweight farmers, high caloric intake may lead to decreasing productivity. Meanwhile, for normal-weight farmers, nutrition status and productivity have a positive association. 
Paddy farmer in Malaysia presents an ideal case study for other countries, especially those that rely on the agricultural economy. We argue that Malaysia offers interesting snapshots, whereas the findings can be generalized for other countries despite several slight differences in economic features. Firstly, most countries are highly dependent on a particular crop for food, rice as the staple food in Malaysia. However, agricultural productivity growth is still slow, which is a prominent trend among countries that depend on rural farmers' agricultural produce. Paddy is widely cultivated by smallholder farmers in rural parts of Malaysia.

Secondly, rural areas share the same characteristics, with these communities mostly belonging to the low-income group and consuming less healthy food. Previous research shows that malnutrition reduces productivity ( $\mathrm{Hu} \&$ Wang, 2019). Considering the strong influence of calories on productivity conditions, we proposed to investigate the relationships between farmers' health status and food intake and their agricultural productivity. This problem is evident among rural farmers, such as in Indonesia, where health status significantly affects productivity (Marliyati et al., 2018). This research differs from previous studies such as Croppenstedt and Muller (2000), LaFave and Thomas (2016), and Strauss (1986). Previously nutrition intake is good due to healthy food availability. Currently, healthy food is expensive, and bad food is cheap. Poorer households consume less healthy food and are more susceptible to unhealthy cheaper food. Lower-income groups have a monotonous diet with little variation (Dowler \& Dobson, 1997). It may be different from Strauss (1986), where more calorie intake leads to better productivity. However, a different scenario may arise from unhealthy, cheaper food, possibly leading to low productivity. Secondly, this study modified Croppenstedt and Muller (2000), LaFave and Thomas (2016), and Strauss (1986) by adding BMI and obesity as moderator variables to contribute to the model.

In sum, the research's first objective is to investigate the relationship between nutritional status and productivity. Secondly, the research aims to determine the relationship between health status and productivity. Lastly, the research examines the moderating effect of health status on the relationship between nutritional status and productivity. We follow and modify the seminal paper of Strauss (1986) and introduce the moderating effect's health status variable. We have extended it to a new empirical context and modified the model according to some measures and definitions. We focus on how health status may play a significant role in the relationship between nutritional status and productivity. We take a different approach which we will explain in the methodology section.

Therefore, the contribution of this research is fourfold. First, to establish mutuality among various literature works, this study's major contribution is the theory extension for the relationship between calorie intake and productivity by adding 
Body Mass Index (BMI) as the moderator. Secondly, the research emphasizes the critical role of calorie intakes for farmers' productivity. Thirdly, this research broadens the theoretical and practical expectations of how this study can be applied to other corresponding studies in developed and developing agricultural nations. Lastly, policymakers can make the practical decision that draws special attention to the study's strengths and limitations to initiate a suitable blueprint that will aid the farmers.

\section{Literature Review}

The research conceptualization of this research is under efficient-wage theory, nutrition-productivity hypothesis, and dual labour-market theory. We contest these three theories to reveal the moderating effect of health status on the relationship between farmers' nutritional status and productivity. This section discusses the existing literature that provides the basis for our hypothesis and thus re-examines the relationship between nutritional status and productivity in the context of farmers' health status.

Efficient-wage Theory. Efficiency wage theory is commonly used to explain food distribution within a household and how it leads to involuntary unemployment (Strauss, 1986). The definition of efficient wage is more on the equilibrium ratio of wage given voluntarily to productivity. If the efficiency wage is met, it motivates the workers to work productivity, or in other words, higher wages boost employee morale and increase worker's productivity.
This theory explains why many labourintensive sectors have lost their workers. With a small efficient wage received in those sectors, labour productivity may decrease. Studies from Harris (2014), Piper (2014), and Strauss (1986) argue that labours cannot afford high nutrition, leading to decreasing productivity. In agriculturalmassive countries, when the wage received by farmers is small, the outcomes will be two: (i) lower productivity due to no energy (biological aspects); and (ii) exit from agricultural sectors and transforming the agricultural land into commercial and industrial properties (Rigg et al., 2018).

Despite the overwhelming evidence of testing this theory, those findings might not prevail in paddy farming for two reasons. First, paddy is partially industrialised in many countries. This makes paddy prices relatively competitive, leading to higher returns than other plantations that are either not-industrialised at all (i.e., vegetables, fruits) or fully industrialised (e.g., palm oil, soybean, rubber, coffee). Second, smallholder paddy farmers could receive a higher government incentive, given the importance of rice as a staple food. The savings of paddy farmers could be relatively higher, leading to better nutrient intake.

\section{Nutrition-Productivity Hypothesis.} The nutrition-productivity hypothesis postulates that nutritional status affects labour productivity. When daily food rations exogenously increased, worker productivity increases. In the seminal study in this area, Kraut and Muller (1946) reported that 
the high caloric intake of German coal miners, steelworkers and workers dumping debris increases their hourly productivity. Wolgemuth et al. (1982) test this hypothesis and show that energy intake is positively related among road construction workers in Kenya. Strauss (1986) is one of the early studies that test this hypothesis within farmers' context. Strauss's findings report that output was increased in Sierra Leone when they had higher caloric intake. Using this hypothesis as a research framework, we argue that farmers with better nutritional status will have higher productivity.

Many studies have provided a rationale for research in nutrition by examining the relationship between nutritional status (calorie intake) and health (Bianchetti et al., 1990; Yu et al., 2003), physical activity (Castetbon et al., 2009), socioeconomic (Bianchetti et al., 1990), productivity (Haddad \& Bouis, 1991; Irvine et al., 2011; Strauss, 1986), cognitive development (Freeman et al., 1980), work performance (Senkal et al., 2002). Most previous studies have a gap in the health economics literature about how nutrition affects each of these characteristics. However, nutritional status and productivity have not been considered in Malaysia. Therefore, we further identify the relationship between nutrition (calorie consumption), BMI (anthropometric or clinical health variables), and productivity.

\section{Hypothesis Development.}

Nutrition (Calorie Intake) and Productivity. Popkin (1978) revealed that improved nutritional status might significantly impact labour productivity. Strauss (1986) shows a highly significant effect of caloric intake on labour productivity. Deolalikar (1988) indicates that market wages or farm output are sensitive to changes in workers' daily energy intake. The human body can adapt to inadequate nutrition in the short run. However, it cannot adapt to readily chronic malnutrition that eventually results in loss of weight-for-height. The marginal effect on productivity falls drastically as caloric consumption rises but remains positive at moderately high intake levels. Suppose households cannot access nutritious food to attain requisite micronutrient requirements. In that case, they typically have poor health, reduced physical performance, and low labour productivity, which reduces economic growth (Croppenstedt \& Muller, 2000). Hu and Wang (2019) indicate that nutritional deficiency can significantly decrease workers' productivity and labour supply in the short term. Tiwasing et al. (2019), indicates that calorie intake contributes to higher farm productivity. Investment in improving productivity is possible by increasing macronutrient consumption.

\section{$H_{1}$ : Higher nutrition leads to an increase in productivity}

\section{Health Status (BMI) and Productivity.} Kedir (2009) established that BMI positively and significantly affects productivity. According to Ulimwengu (2009), production inefficiency increases significantly with the number of days lost to sickness. By measuring health status using BMI, Pagan 
et al. (2016) indicate that obesity negatively affects workers' psychosocial well-being and productivity. According to Goettler et al. (2017), higher BMI in workers imposes significant costs through lost productivity. There is a significant relationship between health status resulting from the presence of central obesity ${ }^{1}$ and the number of days absent from the plantation for health reasons. Farmers suffering from central obesity have a higher number of absent days due to health reasons than farmers not suffering from central obesity (Marliyati et al., 2018). According to Linaker et al. (2020), people from lower socioeconomic positions are more likely to have physically demanding occupations. The implication is that obesity, yet another consequence of low social-economic position increases the risk of premature loss of personal economic productivity.

$\mathrm{H}_{2}$ : Health condition like Body Mass Index has a significant role for farmer's productivity

The Moderation Effect of BMI on the Relationship Between Calorie Intakes and Productivity. Spurr (1983) asserted that body size may have a different effect on labour productivity than daily caloric intake. Farmers are more physically fit because the greater amount of exercise or work compensates for greater caloric intake (Donham \& Thelin, 2016). However, obesity occurs in the farming population mainly due to modern technology implementation such

\footnotetext{
${ }^{1}$ Central obesity is an excess accumulation of fat in the abdominal area.
}

as mechanized farming (Pickett et al., 2015). Obesity can significantly impact farmers' ability to perform farm work (Hunsucker, 2016). Rural residents in India with low BMI require fewer caloric intakes of about 1,100 and 1,400 kcal/day depending on size and gender (Ferro-Luzzi et al., 1997) compared to the most rural population in India that requires approximately $2240 \mathrm{kcal} /$ day per day (Deaton \& Dreze 2009). Rural Muslim farmers in India can spend more time working on the farm than during Ramadan, whereby fasting causes productivity to fall, caused by fewer caloric intakes (Schofield, 2014).

$\mathrm{H}_{3}$ : $\mathrm{BMI}$ moderates the relationship between calorie intake and productivity.

\section{MATERIALS AND METHODS}

Since the main objective of this study is to examine the moderating role of health status on the relationship between nutritional status and productivity of paddy farmers, we provide a brief discussion of the data, the regression model, and all key variables used in this main analysis. The control variables are described in Appendix A.

\section{Data and Sample}

The sampling frame of this research is all paddy farmers in Sarawak. We obtain the data from a field survey via faceto-face interview. The data is limited due to the relatively small population of paddy farmers in Sarawak, around 35,915 farmers. The probability sampling method of stratified random sampling is utilized in this study. The stratum is based on the 
division in the Sarawak area. Choosing the stratum has to meet the criteria that the division is an important area for Malaysia's commercialized paddy plantation.

The criteria for inclusion in our sample are: (1) they must be smallholder paddy farmers, (2) the farmers must reside in the paddy farms area, and (3) the production does not involve a third party. Note that the new paddy commercialization scheme allows the big companies to take over the business chain, from seeding until selling. The owners of paddy farms only receive a proportion of it. Those smallholder farmers who are in this scheme are also excluded. Following this sampling procedure, we follow the sampling size calculation from Sekaran and Bougie (2010) and found it with a population of 35,915 , margin error of $10 \%$, and confidence level of $95 \%$, the minimum sample has to be 96 respondents. This small sample is common for agricultural economics study within specialised plantation (in our case, we only focus on paddy-rice farms) (Chauhan et al., 2006; Dhungana et al., 2004; Kornginnaya, 2013; Montiflor et al., 2008; Saka \& Lawal, 2009; Terano \& Mohamed, 2014; Wadud \& White, 2000). Nevertheless, our field trip successfully reached the final total sample size of 115 farmers after conducting data cleaning and non-response bias test.

\section{Research Model}

The pioneering paper of Strauss (1986) specifies a linear regression model with all contemporaneous variables for the function of productivity. To accommodate the possibility of moderating the effect of health status in line with Hypothesis H3, we extend their specification by including the interaction term between health status and nutrition.

The baseline model is the productivity function following the established model of the farm household model of Singh et al. (1986). The factors of farmer's productivity consist of several families that taking part in an agricultural activity (familylabour ${ }_{i}$ ), a total of hired labour (Hiredlabour ${ }_{i}$ ), total capital (Capital $)$, the total land used for agricultural activities $\left(\operatorname{Land}_{i}\right)$, and the average age of the participants in the agricultural process ( ). The regression model is as follow:

$$
\begin{aligned}
& \text { Productivity }=\beta_{0}+\beta_{1} \text { familylabour }_{i} \\
& +\beta_{2} \text { Hiredlabour }_{i}+\beta_{3} \text { Capital }_{i} \\
& +\beta_{4} \text { Land }_{i}+\beta_{5} \text { Age }_{i}+\varepsilon_{i, t}
\end{aligned}
$$

We introduce the nutrition proxy into model (1) to reveal the effect of nutrition on productivity. The regression model is as follow:

$$
\begin{aligned}
& \text { Productivity } \beta_{0}+\beta_{1} \text { Nutrition }_{i} \\
& +\beta_{2} \text { familylabour }_{i}+\beta_{3} \text { Hiredlabour }_{i} \\
& +\beta_{4} \text { Capital }_{i}+\beta_{5} \text { Land }_{i} \\
& +\beta_{6} \text { Age }_{i}+\varepsilon_{i, t}
\end{aligned}
$$

We argue that there is a possibility of a non-linear effect of nutrition on productivity. The nutrition effect may diminish productivity at a certain point. 
This argument is consistent with health literature findings that overeating is bad for human activity resulting in decreasing health conditions (Mozaffarian, 2016). To accommodate the possibility of a nonlinear relationship, we add the quadratic value of nutrition as another predictor for productivity. The regression model is as follow:

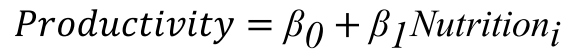

$$
\begin{aligned}
& +\beta_{2} \text { Nutrition }^{2}{ }_{i}+\beta_{3} \text { familylabour }_{i} \\
& +\beta_{4} \text { Hiredlabour }_{i}+\beta_{5} \text { Capital }_{i} \\
& +\beta_{6} \text { Land }_{i}+\beta_{7} \text { Age }_{i}+\varepsilon_{i, t}
\end{aligned}
$$

As our final regression model, we specify the estimation by introducing two variables: the moderating variable (health status) and the interaction term between nutrition and health status (Nutrition* Health Status). The regression model is as follow:

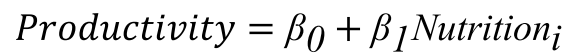

$$
\begin{aligned}
& +\beta_{1} \text { Nutrition }_{i}+\beta_{2} \text { Nutrition }^{2}{ }_{i} \\
& +\beta_{3} \text { Health }_{i}+\beta_{4} \text { Nutrition } * \text { Health } i \\
& +\beta_{5} \text { familylabour }_{i}+\beta_{6} \text { Hiredlabour }_{i} \\
& +\beta_{7} \text { Capital }_{i}+\beta_{8} \text { Land }_{i}+\beta_{9} \text { Age }_{i} \\
& +\varepsilon_{i, t}
\end{aligned}
$$

\section{Variable Definition}

Productivity. Based on Cobb and Douglas's (1928) theory of production, the measurement for physical production is quantified by changes in the amount of labour and capital which are used to produce goods and secondly to discover the relationship that exists within the factors of labour, capital, and product. However, it was an early attempt to investigate productivity for the manufacturing industry. Hence, recent studies have included the theory in investigating agricultural productivity (Dharmasiri, 2012). Additionally, Data Envelopment Analysis (DEA) is applied in examining agricultural production efficiency. (Linh, 2012; Wadud \& White, 2000).

Data Envelopment Analysis (DEA) is used to measure paddy farmers' productivity for this research. The selection of the following outputs and inputs is selected based on Chauhan et al. (2006) to measure the productive efficiency of paddy farmers. The inputs are paddy inventory, machinery, total cultivated land, hours worked, hired labour. Meanwhile, the output in the form of paddy production was selected to measure efficiency in paddy production.

$$
\text { Productivity }=\frac{\text { Weighted Sum of Inputs }}{\text { Weighted Sum of Ouputs }}
$$

Nutrition. The measurement follows Strauss's (1986) paper, whereby the effect of current nutritional status is based on the monthly caloric intake on monthly farm production. Furthermore, we consider calorie consumption expressed in kilocalories (kcal) as an indicator of food access (Euler et al., 2017). Data on monthly food consumption were collected, and using 
food composition tables from the Malaysian Food Composition Database (2020), data on the number of different foods consumed were converted to calories to get an estimate of household calorie consumption (De Haen et al., 2011). We adopt from calorie-intake inventory (Strauss, 1986), which is later commonly used in agricultural economics research such as Glewwe et al. (2001), Ogbuoji et al. (2020), and Strauss and Thomas (1998). The total household calorie consumption from the 30-day recall was then divided by 30 to obtain a calorie value per day.

Health Status. This research adopts the same procedure as past research conducted by Ulimwengu (2009), which empirically used Body Mass Index (BMI) as an indicator of health status. To ensure that the results are accurate, this research has two separate steps to measure BMI. First, the BMI score is used as a measure whereby it is defined as weight in kilograms divided by height in meters squared $\left(\mathrm{kg} / \mathrm{m}^{2}\right)$. The second measure is the categorical variable of BMI. Following the World Health Organization (2000), we treat normal (BMI score: $18.5-24.9 \mathrm{~kg} / \mathrm{m}^{2}$ ), overweight (BMI score: $25-29.9 \mathrm{~kg} / \mathrm{m}^{2}$ ), and obese (BMI score: $>30 \mathrm{~kg} / \mathrm{m}^{2}$ ). In medical literature, overweight and obesity share similar risk and activity levels. Therefore, the reading will be 0 for normal and 1 for non-normal (overweight and obese).

\section{RESULTS AND DISCUSSIONS}

\section{Descriptive Statistics}

Table 1 presents the summary statistics for the variables in the estimation model. Focusing on the key variables, the mean value of productivity is 0.3092 with a minimum value and a maximum value of 0.05 and 1 . This implies two important descriptive findings. First, the productivity of paddy farmers is averagely low. The median value of 0.228 confirms our conclusion where $50 \%$ of farmers in low productivity level. Second, the variance of productivity level is good. We have a farmer with near zero productivity and a farmer with a perfect productivity level. The nutrition level shows that the meant caloric intake is $2,612 \mathrm{kcal}$ per day per farmer. The range is good with

Table 1

Summary statistics of 115 paddy farmers

\begin{tabular}{lccccc}
\hline & Minimum & Maximum & Mean & Std. Deviation & Median \\
\hline Age (year) & 23.00 & 83.00 & 54.487 & 12.974 & 54.00 \\
Land (acre) & 1.00 & 4.00 & 1.950 & 0.897 & 2.00 \\
Family labour & 1.00 & 4.00 & 1.530 & 0.666 & 1.00 \\
Hired Labour & 1.00 & 4.00 & 1.320 & 0.600 & 1.00 \\
Capital (rm) & 0.00 & 4150.00 & 786.455 & 727.095 & 500 \\
BMI (kg/m2) & 20.05 & 46.66 & 26.366 & 4.315 & 25.80 \\
Calorie (kcal/day) & 1341.16 & 3557.486 & 2612.497 & 625.663 & 2216 \\
Productivity (log) & 0.05 & 1.00 & 0.309 & 0.249 & 0.228 \\
\hline
\end{tabular}


one farmer with 1,341 kcal per day and a farmer with a very high-calorie intake (7,557 kcal). Our anecdotal evidence reveals that farmers with low and high-calorie intake have the lowest and highest productivity, respectively. Lastly, the BMI score's health status shows that the farmers' average BMI is 26 , implying farmers are overweight. The lowest value of BMI is $20 \mathrm{~kg} / \mathrm{m} 2$ implying an ideal weight category. Interestingly, we have a farmer with a very high BMI, which $46.66 \mathrm{~kg} / \mathrm{m} 2$ implying obesity level 3 . Note that the lowest and highest BMI score is not from the farmer with the lowest and highest productivity level.

\section{Result Analysis}

Nutritional Status and Productivity. Table 2 consists of three columns, columns (1), (2), and (3). Column (1) shows the results of the baseline model for this study from estimation model 1. Column (2) reveals the results of the estimation model (2). Lastly, Column (3) reports the regression results from Model (3).

The findings from Columns (1), (2), and (3) are consistent. First, all the control variables share a similar conclusion. Family labour and land have significant effects on productivity. Higher family labour leads to lower productivity. Meanwhile, higher cultivated land leads to better productivity.

Table 2

Nutrition results

\begin{tabular}{lccc}
\hline & 1 & 2 & 3 \\
\hline Calorie & & $-0.0153^{* * *}$ & $-0.0458^{* *}$ \\
calorie2 & & $(0.003)$ & $0.019)$ \\
& & & $(0.0003 *$ \\
Family Labour & $-0.0712^{* *}$ & $-0.0637 * *$ & $-0.0708^{* * *}$ \\
& $(0.032)$ & $(0.026)$ & $(0.025)$ \\
Hired Labour & 0.05 & 0.0462 & $0.0504 *$ \\
& $(0.037)$ & $(0.0290)$ & $(0.028)$ \\
Capital & 0.0529 & 0.0286 & 0.0268 \\
& $(0.0338)$ & $(0.0300)$ & $(0.0300)$ \\
Land & $0.0897 * * *$ & $0.0709 * * *$ & $0.0696 * * *$ \\
& $(0.020)$ & $(0.019)$ & $(0.019)$ \\
Age(Ln) & -0.0326 & -0.0324 & -0.0669 \\
& $(0.084)$ & $(0.062)$ & $(0.060)$ \\
Constant & 0.0937 & $0.7114 * *$ & $1.3170 * * *$ \\
& $(0.381)$ & $(0.272)$ & $(0.456)$ \\
\hline R-Squared & 0.1557 & 0.3482 & 0.3734 \\
F Value & 6.54 & 10.22 & 9.43 \\
\hline
\end{tabular}

Note: $*, * * * *$ indicate the significant level for $1 \%, 5 \%$, and $10 \%$, respectively. The values stated are beta coefficient values, except the value inside parentheses which are standard error values. 
Total hired labour, total capital, and average age do not affect productivity.

For the key variables, Column (2) and Column (3) surmise that the relationships between nutritional status and productivity are non-trivial. These columns show a negative association indicating higher caloric intake leads to decreasing productivity. In other words, a farmer with a higher nutrition intake (calorie intake) will end with low productivity. To tackle the issue of non-linear relationships, Column (3) reveals the quadratic value of nutrition. It shows a positive association between nutritional status and productivity after the nutrition is under the quadratic form. Therefore, we can surmise that nutrition does discount the farmer's productivity. Nevertheless, this relationship was below a U-shaped relationship where there is a point where productivity increases again when nutritional intake is adequate.

\section{Full Model Results}

In this section, all three hypotheses, $\mathrm{H}_{1}, \mathrm{H}_{2}$, and $\mathrm{H}_{3}$, are empirically tested to achieve the research objectives. The results are presented in Table 3. For robustness, the measure of health status in Column (1) and Column (2) is different from the measure used for Column (3) and Column (4). Column (1) and Column (2) use the BMI score as the measure whereby is defined as weight in kilograms divided by height in meters squared $\left(\mathrm{kg} / \mathrm{m}^{2}\right)$. Column (3) and Column (4) use the categorical variable of health status. We treat normal (BMI score: 18.5-24.9 kg/m²), overweight (BMI score:
25-29.9 $\mathrm{kg} / \mathrm{m}^{2}$ ), and obese (BMI score: > 30). In medical literature, overweight and obesity share similar risk and activity levels. Therefore, the measurement will be 0 for normal and 1 for non-normal (overweight and obesity).

In Hypothesis 1 (H1), we hypothesize a positive relationship between nutritional status and productivity. The results in Column (2) of Table 3 reveal a negative association between nutritional status and productivity $(\beta=-.0969 \mathrm{SE}=0.022)$. It suggests that more nutrition intake or more calorie intake receives a lower proportion of productivity. Practically, this result suggests that one-unit change of nutrition intake (calorie intake) is associated with 0.0969 decreases in productivity level, which is consistent with Camacho and Ruppel (2017), whereby high-calorie consumption leads to be laziness, which are the symptoms of obesity and overweight. The similarities reaffirm Goettler et al. (2017) findings which indicate productivity loss due to obesity and overweight. The findings are not supported by the efficiency wage theory, where more caloric intakes make a farmer less productive.

We also test Hypothesis 2 about the significant role of health status on productivity. Column (2) reveals that health status is statistically significant and contributed negatively to productivity. It indicates that larger health status leads to lower productivity of the farmers. An increase of one unit of health status decreases the productivity of -0.1045 for Column (2). The result is reaffirming (Goettler et al., 
2017; Linaker et al., 2020; Marliyati et al., 2018) research, whereby the studies found that overweight and obesity to be associated with decreasing levels of productivity.

For the main research objective (H3), we examine the interaction term effect to reveal the moderating effect of health status on the relationship between nutritional status and productivity. Column (2) reports the moderating effect of the interaction term between nutrition and health status is statistically significant at a $1 \%$ significance level with a coefficient value of 0.0026 . It implies that the moderating effect has a positive relationship with productivity where the higher the interaction term between nutrition and health status, the higher the productivity. In economics terms, a one-unit increase in the interaction term between nutrition and health status increases productivity by 0.0026 for Column (2). Hence, the outcome of the findings is aligned with Donham and Thelin (2016) and Spur (1983), whereby health status strengthens the findings of a positive effect of nutrition on productivity. Therefore, health status and nutrition are two important factors in increasing productivity.

As a robustness check, we re-estimate model (4) with an alternative measure of health status. This moderating variable is measured under the dummy variable. The other measures remain the same. Re-testing Hypothesis 1 (H1), we find that nutrition has a positive relationship between nutritional status and productivity. The results in Column (4) of Table 3 reveal a negative association between nutritional status and productivity $(\beta=-.0472 \mathrm{SE}=0.011)$. It suggests that more nutrition intake or more caloric intake receives a lower proportion of productivity. Practically, this result suggests that the one-unit change of nutrition intake is associated with 0.0472 decreases in productivity levels. It is consistent with our findings in Column (2).

We also re-test Hypothesis 2, and Column (4) reveals that health status has a non-trivial relationship with productivity ( $\beta=-.5746 \mathrm{SE}=0.137)$, indicating a positive relationship. It suggests that the productivity of farmers with overweight or obesity is significantly different from farmers' productivity with normal health status, and the difference is up to .5746 . The coefficient value suggests that farmers' productivity with overweight or obesity condition is underperformed compared to farmers with normal health status. This result is also consistent with our result in Column (2).

Lastly, the re-test of $\mathrm{H} 3$ surmises the same conclusion. The interaction term is significant, implying a significant moderation effect $(\beta=.0137 \mathrm{SE}=0.004)$. The positive coefficient means that health status strengthens the relationship between nutritional status and productivity. Practically, productivity of farmers with overweight or obesity will increase due to higher calorie intake.

\section{Moderation Effect}

We further study the moderation impact by following Dawson (2014); thus, we plot it in Figures 1 and 2. This interaction is illustrated in Figure 1, where the model 
Table 3

Health status moderation results

\begin{tabular}{|c|c|c|c|c|}
\hline & 1 & 2 & 3 & 4 \\
\hline \multirow[t]{2}{*}{ Nutrition } & $-0.0417 * *$ & $-0.0969 * * *$ & $-0.0370 * *$ & $-0.0472 * * *$ \\
\hline & $(0.018)$ & $(0.022)$ & $(0.016)$ & $(0.011)$ \\
\hline \multirow[t]{2}{*}{ Nutrition2 } & 0.0004 & 0.0002 & 0.0004 & 0.0002 \\
\hline & $(0.000)$ & $(0.000)$ & $(0.000)$ & $(0.000)$ \\
\hline \multirow[t]{2}{*}{ HealthStatus } & $-0.0134 * * *$ & $-0.1045 * * *$ & $-0.1159 * * *$ & $-0.5746^{* * *}$ \\
\hline & $(0.004)$ & $(0.028)$ & $(0.027)$ & $(0.137)$ \\
\hline \multirow[t]{2}{*}{ Nutrition*HealthStatus } & & \multicolumn{2}{|c|}{$0.0026^{* * *}$} & $0.0137 * * *$ \\
\hline & & $(0.001)$ & & $(0.004)$ \\
\hline \multirow[t]{2}{*}{ Family Labour } & $-0.0680 * * *$ & $-0.0705 * * *$ & $-0.0548 * *$ & $-0.0569 * * *$ \\
\hline & $(0.024)$ & $(0.023)$ & $(0.023)$ & $(0.022)$ \\
\hline \multirow[t]{2}{*}{ Hired Labour } & $0.0607 * *$ & $0.0605 * *$ & $0.0525^{* *}$ & $0.0576^{* *}$ \\
\hline & $(0.027)$ & $(0.026)$ & $(0.026)$ & $(0.025)$ \\
\hline \multirow[t]{2}{*}{ Capital } & 0.0072 & 0.026 & -0.0039 & 0.0159 \\
\hline & $(0.028)$ & $(0.028)$ & $(0.027)$ & $(0.026)$ \\
\hline \multirow[t]{2}{*}{ Land } & $0.0467 * * *$ & $0.0580^{* * *}$ & $0.0391 * *$ & $0.0538 * * *$ \\
\hline & $(0.017)$ & $(0.016)$ & $(0.017)$ & $(0.016)$ \\
\hline \multirow[t]{2}{*}{ Age(Ln) } & -0.0601 & -0.0742 & -0.049 & -0.0622 \\
\hline & $(0.059)$ & $(0.057)$ & $(0.056)$ & $(0.055)$ \\
\hline \multirow[t]{2}{*}{ Constant } & $1.6650 * * *$ & $3.7715 * * *$ & $1.4376^{* * *}$ & $1.9467 * * *$ \\
\hline & $(0.419)$ & $(0.744)$ & $(0.389)$ & $(0.369)$ \\
\hline R-Squared & .4193 & .4675 & .4568 & .5073 \\
\hline F Value & 8.7 & 9.68 & 10.22 & 13.37 \\
\hline
\end{tabular}

Note: $* * *, * *$ indicate the significant level for $1 \%, 5 \%$, and $10 \%$, respectively. The values stated are beta coefficient values, except the value inside parentheses which are standard error value

uses the BMI score. As shown in Figure 1, both the low and high BMI curves show a decline from low-calorie intakes to highcalorie intakes. The curves then intersect at high-calorie levels. From the curve in Figure 1, farmers with high BMI scores are more productive than farmers with low BMI scores when caloric levels are high.

Meanwhile, the interaction is presented in Figure 2, where the model uses the categorical indicator. As depicted in Figure 2 , both the low and high BMI curves show an inclined projection as higher caloric levels. The curves intercept at high caloric levels, and similar to Figure 1, farmers with high BMI shows to be more productive than low BMI farmers when calorie intakes are high.

Table 4 of Cohen's $F^{2}$ reconfirms the results by showing a small moderation effect. As shown in Table 4, calorie intake was significantly related to productivity, and BMI significantly moderated this relationship. 
Azra Tilai, Rayenda Khresna Brahmana and Hui Wei You

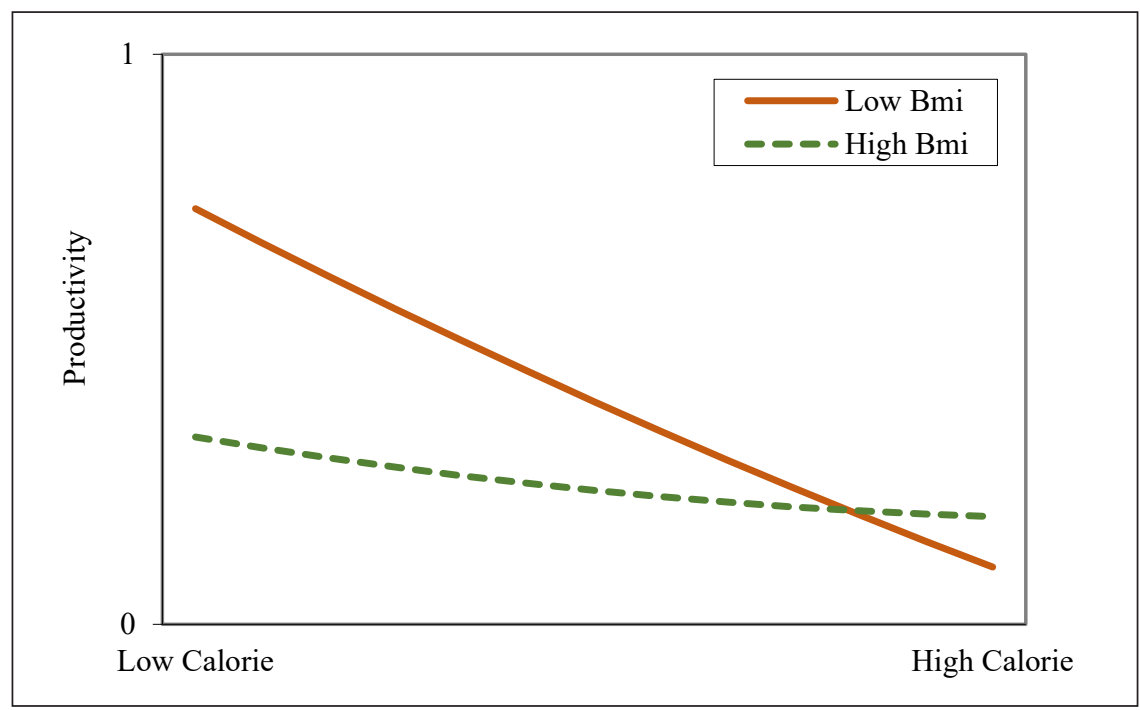

Figure 1. Model is using the BMI score

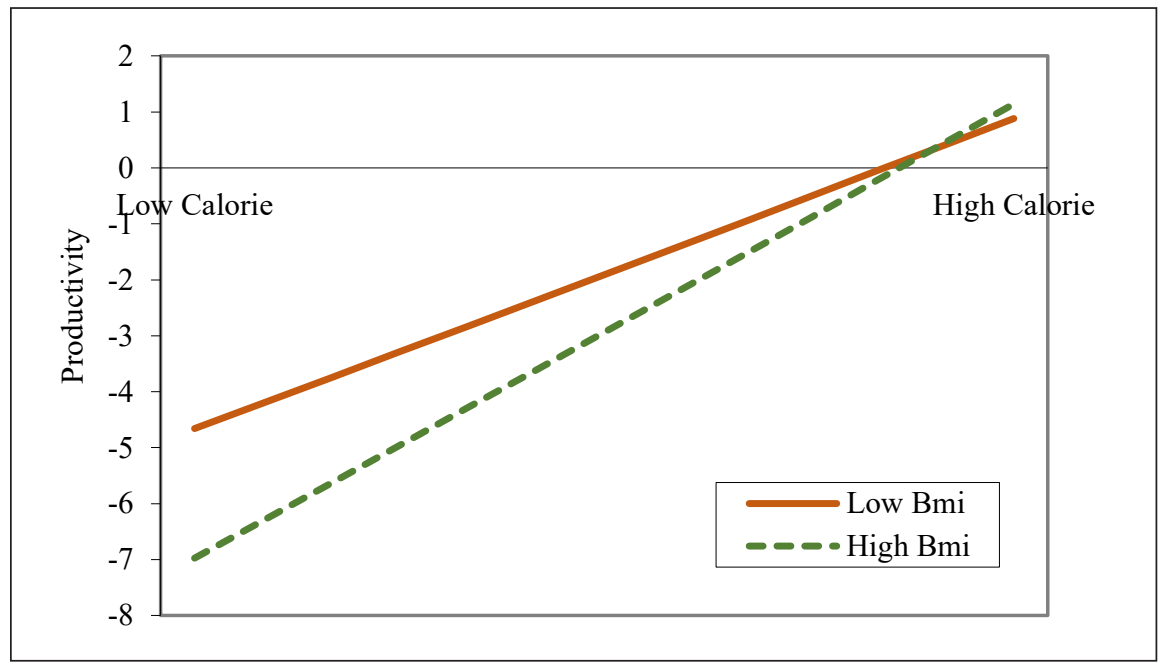

Figure 2. The model is using the categorical indicator

Table 4

Cohen F-squared results

\begin{tabular}{lcc}
\hline & Hi-Lo BMI & Normal-Overweight \\
\hline R-Squared with Moderation & 0.4675 & 0.5073 \\
R-Squared without Moderation & 0.4193 & 0.4568 \\
F-Squared & 0.090516 & 0.102496 \\
Conclusion & Small & Small \\
\hline
\end{tabular}




\section{Robustness Check I: Sub-Sampling Results Splits of Normal - Overweight farmer.}

As a robustness check, we omit the BMI variable from equations (4), (5), (6), and (7) and employ a sub-sampling approach. We further run the robustness check to confirm the results from Table 1 and Table 2. We divide the sample into two groups. The first group is normal weight, with a BMI index between 19 and 25, and the second group is overweight, with a BMI index higher than 25. The total number of respondents with normal BMI was 67 respondents. Meanwhile, 48 farmers were in the overweight condition. After regrouping the sample, we run our new estimation model ${ }^{2}$ using a sub-sampling approach and report it in Table 4.

Table 5 summarizes that the sub-sample results show a similar conclusion between normal farmer groups and overweight farmer groups. Calorie has a significant effect on productivity for both normal and overweight farmer groups. Both normal and overweight farmer group indicates higher-calorie leads to lower productivity.

${ }^{2}$ Productivity $=\beta_{0}+\beta_{1}$ Calorie $_{i, t}+\beta_{2}$ Calorie $_{i, t}$ $+\beta_{3}$ familylabour $_{i, t}+\beta_{4}$ Hiredlabour $_{i, t}+\beta_{5}$ Capital $_{i, t}$ $+\beta_{6}$ Land $_{i, t}+\varepsilon_{i, t}$

Table 5

Body mass sub-sampling results

\begin{tabular}{lcccc}
\hline & \multicolumn{2}{c}{ Normal $(\mathrm{n}=67)$} & \multicolumn{2}{c}{ Overweight $(\mathrm{n}=48)$} \\
\cline { 2 - 5 } Calorie & 8 & 9 & $-0.0070^{* * *}$ & $-0.0243^{*}$ \\
calorie2 & $(0.004)$ & $-0.0396^{*}$ & $(0.002)$ & $(0.013)$ \\
Family Labour & & $(0.020)$ & & 0.0003 \\
& & 0.0003 & & $(0.000)$ \\
Hired Labour & -0.1252 & $(0.000)$ & $-0.0345^{*}$ & $-0.0368^{* *}$ \\
& $(0.076)$ & $-0.1390^{*}$ & $(0.019)$ & $(0.018)$ \\
Capital & 0.1151 & $(0.077)$ & $0.0429 *$ & $0.0464 * *$ \\
& $(0.084)$ & 0.106 & $(0.023)$ & $(0.023)$ \\
Land & 0.0133 & $(0.080)$ & 0.021 & 0.0223 \\
& $(0.076)$ & 0.0048 & $(0.025)$ & $(0.025)$ \\
Age(Ln) & $(0.079)$ & $0.0437 * * *$ & $(0.013)$ & $0.0430^{* * *}$ \\
& $0.1013 *$ & $0.1026^{*}$ & $-0.1299^{* *}$ & $(0.013)$ \\
Constant & $(0.057)$ & $(0.057)$ & $(0.058)$ & $-0.1382^{* *}$ \\
& 0.0631 & 0.022 & $0.8126^{* * *}$ & $(0.057)$ \\
R-Squared & $(0.119)$ & $(0.131)$ & $(0.257)$ & $1.1156^{* * *}$ \\
F Value & 0.6164 & 1.0674 & 0.3362 & $(0.329)$ \\
\hline
\end{tabular}

Note: $* * *, * *$ indicate the significant level for $1 \%, 5 \%$, and $10 \%$, respectively. The values stated are beta coefficient values, except the value inside parentheses which are standard error value 
The estimation coefficients are interpreted as a one-unit increase of calories, leads to a $2.25 \%$ decrease in productivity or a 0.0040 decrease for the normal farmer group. In the overweight farmer group, an increase in calories will reduce productivity by about $0.70 \%$.

\section{Robustness Check II: Effect of Land}

Ownership. As an alternative robustness check, we perform another subsample for equation (2) to (7), where we re-run the farmer according to scale land. We divide our total sample into two groups: low and high-scale land groups. It is for robustness check to ensure the effect of land ownership. One can argue that the nutrition-productivity relationship is due to the farmer's land ownership. Farmers with small land may not require higher calorie intake compared to large land ownership farmers. We divide the sample into two groups. The first group is small-scale land, where land ownership is lower or equal to the median. The second group is large-scale landowners, where land ownership is higher than the median. We re-run the estimation model and report it in Table 6.

The results are not very different. Calories harm productivity for low-scale land and high-scale land groups. The estimation coefficients are interpreted as a one-unit increase in calories, leads to a $9.75 \%$, and $3.90 \%$ decrease in productivity or a 0.0270 and 0.0170 decrease in productivity for the small-scale land group in column 15 and column 17, respectively, where Full Model means. In a high-scale land group, an increase in calories will reduce productivity by about $9.57 \%$ and $5.17 \%$ or reduce 0.0320 and 0.0170 , respectively, in column 21 and column 23.

BMI has a negative effect on productivity for low and high-scale land groups. The estimation coefficients are interpreted as a one-unit increase of calories, which leads to a decrease of $10.23 \%$ and $52.47 \%$ of productivity or leads to a decrease of 0.0360 and 0.1710 for the smaller-scale land group column 15 and column 17, respectively, where Full Model means. In the high-scale land group, an increase of calories will reduce the productivity of about $11.09 \%$ and $65.11 \%$ or reduce 0.0070 and 0.1800 of productivity, respectively, in column 21 and column 23.

The findings recommend two important conclusions. First, BMI is more important than calories in knowing productivity. In Table 1, one calorie is positively significant for another level of productivity. Meanwhile, Table 5 reports that BMI index is an essential factor for productivity, whether the farmer is normal weight or obese. Consequently, BMI plays a vital character in decreasing productivity, and yet, calories will strengthen that relationship.

Secondly, calorie is a significant factor for productivity, even in different situations such as normal or overweight farmer groups and low or high scale land. Moreover, Table 5 shows that the moderation results have the same conclusion as Table 2 and Table3. This acknowledges that calorie is strengthened by the relationship between BMI and productivity. 


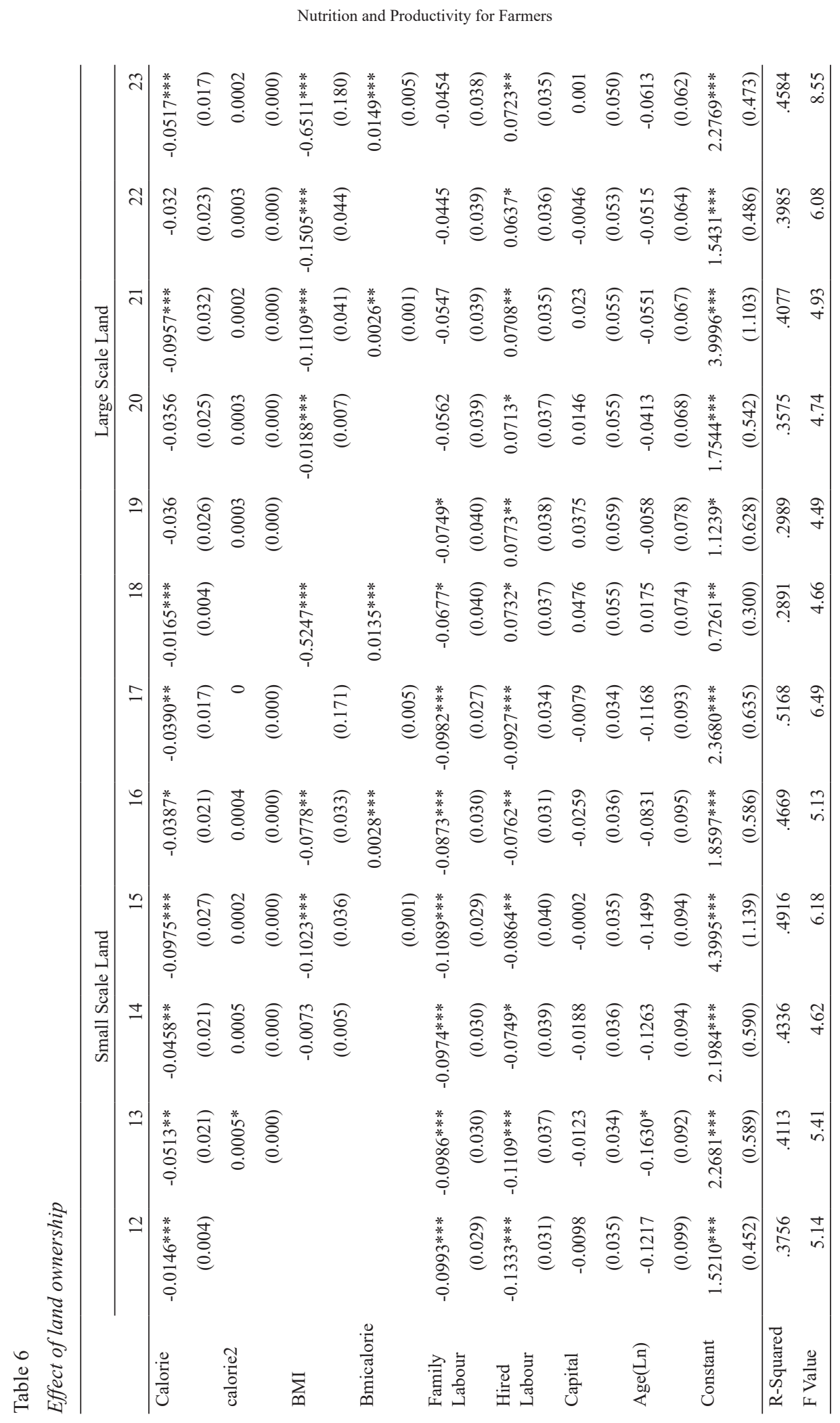

Pertanika J. Soc. Sci. \& Hum. 29 (2): 1125 - 1150 (2021) 


\section{Implication}

To understand the coefficients, we measure the implied output elasticities and marginal products. Table 7 reports them using the estimates from Model 3 of Table 1. Other stipulations offer approximately similar patterns. The estimates show roughly constant returns to scale. Interestingly, the model estimates without the calorie function (col. 1) imply a return to scale of 0.381 . Family labour has a calorie elasticity, and marginal product effects from the logreciprocal specifications of the effective

\section{Table 7}

Output elasticities and marginal product at sample mean

\begin{tabular}{lcc}
\hline & Elasticity & Marginal Effect \\
\cline { 2 - 3 } & ey/ex & $\mathrm{dy} / \mathrm{dx}$ \\
\hline Calorie & -4.919 & -0.046 \\
calorie2 & 1.807 & 0.000 \\
Family Labour & -0.350 & -0.071 \\
Hired Labour & 0.215 & 0.050 \\
Land & 0.616 & 0.070 \\
\hline
\end{tabular}

family labour function are lower, -0.350 and -0.071 , respectively. Calories have calories elasticity and marginal products, which are -4.919 and -0.046 . Both are sizable, negative signs, and statistically significant. Table 7 of the magnitude of this elasticity differs expansively from high-consumption to lowconsumption households.

The estimated efficiency units of labour function are designed in Figure 3. It depicts the relation efficiency of an hour of labour compared with labour that consumes calories equal to the sample mean. The function peaks at a daily intake per consumption equivalent of $6,400 \mathrm{kcal} / \mathrm{day}$, and thereafter calories have a positive impact on effective labour. The corresponding value of $\mathrm{h}($ ) is 0.25 . Roughly 2.5 percent of the sample ( 3 households) have an estimated daily caloric intake per consumer equivalent above this level. This is an enormously significant intake level for calories to negatively affect; however, the effective labour function is flat

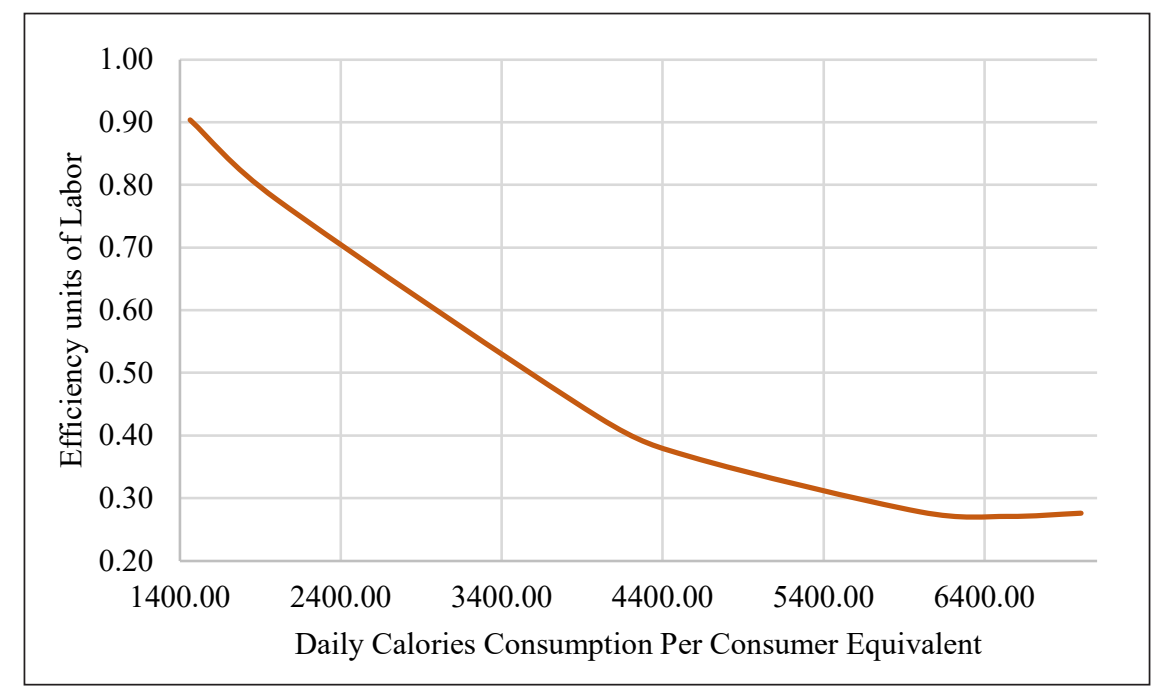

Figure 3. Estimated productivity function 
by the level of 5,900 kcal/day (h is 0.28 ), roughly the average intake of the upper third of the sample. Indeed, this function rises very gently after 4000 calories ( $h$ being 0.43). The flattening of the effective labour function is also evident in the decrease in the elasticity of $\mathrm{h}($ ) with respect to calories from 0.55 at the sample mean intake to 0.35 at 4,500 kcal/day. For households with low per-consumer calorie consumption, the corresponding $\mathrm{h}(-)$ falls much more sharply. At an intake of $1500 \mathrm{kcal}$, the calorie elasticity is .90. The level of $h\left(^{\circ}\right)$ is roughly 0.9 , implying that most of the estimated input elasticities are low for the average set of inputs.

\section{CONCLUSIONS}

Our study is the first empirical investigation to uncover the relationship between nutrition and agricultural productivity among smallholder paddy farmers in Malaysia. We examine our research hypotheses using calories as proxies for nutrient intake, which has caused a decline in current agricultural labour productivity. These effects appear to be crucial at high intakes and much smaller at lower intakes. The effect is further amplified when BMI (health status) is added as a moderator of the relationship between nutritional status and productivity.

Agricultural labour in Malaysia contributes significantly to the country's labour productivity. Therefore, our results are an incredible source of information to justify the significant role of farmers' nutrition in productivity. They are supported by the nutrition-productivity hypothesis and dual labour market theory. The allocative effects of good nutrition are crucial and the results have underestimated the impact of better nutrition on production supply.

To investigate this issue, some questions remain about the relationship between nutritional status and productivity. Interestingly, our results showed that calorie intake causes low productivity. Our results show the relationship with health status as also evident in the earlier study by Strauss (1986). We found that high-calorie intake is further reinforced by the outcome of BMI (anthropometric or clinical health variables). The result shows that the estimated productivity function has a negative relationship. The study shows that BMI and calories will have a negative impact on farm productivity. The study will help farmers, economists, researchers, policymakers, industry practitioners, and the government to have a deeper understanding of the impact of BMI and calories in rural Malaysia. In addition, the study fills the gap of Strauss (1986) and deepens the nutrition productivity hypothesis.

However, all our findings need to be validated by further research in other research settings to verify some facts or limitations of the research design. For example, future research could consider a broader range of smallholder farmers from different plantation types. This study uses a survey design that may under- or over-report caloric intake or production factors. Future research could incorporate experimental studies to represent actual farmer behaviour. In the meantime, agricultural economics 
research in emerging countries is crucial as it could improve the productivity of the farming system, which is imperative to understand. Therefore, we suggest that future studies could further expand nutritional status and productivity in relation to other developing countries.

\section{ACKNOWLEDGEMENTS}

The authors would like to thank the paddy farmers in Sarawak for their valuable responses and their cooperation is given to conduct this research. This research acknowledges the financial assistance from Universiti Malaysia Sarawak through Special Grant No. MYRA F01/ SpMYRA/1678/2018.

\section{REFERENCES}

Aromolaran, A. B. (2004). Household income, women's income share and food calorie intake in South Western Nigeria. Food Policy, 29(5), 507-530. https://doi.org/10.1016/j. foodpol.2004.07.002

Badi, M. A., \& Ba-Saddik, I. A. (2016). Severe acute malnutrition among hospitalized children, Aden, Yemen. Open Journal of Epidemiology, 6(2), 121-127. http://dx.doi.org/10.4236/ ojepi.2016.62012

Bunker, V. W., Lawson, M. S., Stansfield, M. F., \& Clayton, B. E. (1987). Nitrogen balance studies in apparently healthy elderly people and those who are housebound. British Journal of Nutrition, 57(2), 211-221. https://doi. org/10.1079/BJN19870027

Bianchetti, A., Rozzini, R., Carabellese, C., Zanetti, O., \& Trabucchi, M. (1990). Nutritional intake, socioeconomic conditions, and health status in a large elderly population. Journal of the American Geriatrics Society, 38(5), 521-526. https://doi. org/10.1111/j.1532-5415.1990.tb02401.x

Camacho, S., \& Ruppel, A. (2017). Is the calorie concept a real solution to the obesity epidemic? Global Health Action, 10(1), 1-12. https://doi.or g/10.1080/16549716.2017.1289650

Castaneda, C., Charnley, J. M., Evans, W. J., \& Crim, M. C. (1995). Elderly women accommodate to a low-protein diet with losses of body cell mass, muscle function, and immune response. The American Journal of Clinical Nutrition, 62(1), 30-39. https://doi.org/10.1093/ajen/62.1.30

Castetbon, K., Vernay, M., Malon, A., Salanave, B., Deschamps, V., Roudier, C., Oleko, A., Szego, E., \& Hercberg, S. (2009). Dietary intake, physical activity and nutritional status in adults: the French nutrition and health survey (ENNS, 2006-2007). British Journal of Nutrition, 102(5), 733-743. https://doi. org/10.1017/S0007114509274745

Chandra, R. K. (1992). Effect of vitamin and trace-element supplementation on immune responses and infection in elderly subjects. Lancet, 340(8828), 1124-1127. https:// doi.org/10.1016/0140-6736(92)93151-C

Chauhan, N. S., Mohapatra, P. K., \& Pandey, K. P. (2006). Improving energy productivity in paddy production through benchmarking - An application of data envelopment analysis. Energy Conversion and Management, 47(910), 1063-1085. https://doi.org/10.1016/j. enconman.2005.07.004

Cobb, C. W., \& Douglas, P. H. (1928). A theory of production. The American Economic Review, 18(1), 139-165. https://www.aeaweb. org/aer/top20/18.1.139-165.pdf

Croppenstedt, A., \& Muller, C. (2000). The impact of farmers' health and nutritional status on their productivity and efficiency: Evidence 
from Ethiopia. Economic Development and Cultural Change, 48(3), 475-502. https://doi. org/10.1086/452607

Darmon, N., \& Maillot, M. (2010). In foods, energy is cheap where it is abundant and expensive where it is scarce: This is a fact, not an artifact. The American Journal of Clinical Nutrition, 91(4), 1068-1069. https://doi. org/10.3945/ajen.2010.29176

Dawson, J. F. (2014). Moderation in management research: What, why, when, and how. Journal of Business and Psychology, 29(1), 1-19. https:// doi:10.1007/s10869-013-9308-7

De Haen, H., Klasen, S., \& Qaim, M. (2011). What do we really know? Metrics for food insecurity and undernutrition. Food Policy, 36(6), 760-769. https://doi.org/10.1016/j.foodpol.2011.08.003

Deaton, A., \& Drèze, J. (2009). Food and nutrition in India: Facts and interpretations. Economic and Political Weekly, 44(7), 42-65.

Deolalikar, A. B. (1988). Nutrition and labor productivity in agriculture: Estimates for rural South India. The Review of Economics and Statistics, 70(3), 406-413. https://doi. org/10.2307/1926778

Dharmasiri, L. M. (2012). Measuring agricultural productivity using the Average Productivity Index (API). Sri Lanka Journal of Advanced Social Studies, 1(2), 25-44. http://dx.doi. org/10.4038/sljass.v1i2.4855

Dhungana, B. R., Nuthall, P. L., \& Nartea, G. V. (2004). Measuring the economic inefficiency of Nepalese rice farms using data envelopment analysis. Australian Journal of Agricultural and Resource Economics, 48(2), 347-369. https://doi. org/10.1111/j.1467-8489.2004.00243.x

Donham, K. J., \& Thelin, A. (2016). Agricultural medicine: Rural occupational and environmental health, safety, and prevention. John Wiley \& Sons.
Dowler, E. A., \& Dobson, B. M. (1997). Nutrition and poverty in Europe: An overview. Proceedings of the Nutrition Society, 56(1A), 51-62. https://doi. org/10.1079/PNS19970009

Efthimiou, J., Fleming, J., Gomes, C., \& Spiro, S. G. (1988). The effect of supplementary oral nutrition in poorly nourished patients with chronic obstructive pulmonary disease. American Journal of Respiratory and Critical Care Medicine, 137(5), 1075-1082. https://doi. org/10.1164/ajrccm/137.5.1075

Euler, M., Krishna, V., Schwarze, S., Siregar, H., \& Qaim, M. (2017). Oil palm adoption, household welfare, and nutrition among smallholder farmers in Indonesia. World Development, 93, 219-235. https://doi.org/10.1016/j.worlddev.2016.12.019

Fahmi, Z., Samah, B. A., \& Abdullah, H. (2013). Paddy industry and paddy farmers wellbeing: A success recipe for agriculture industry in Malaysia. Asian Social Science, 9(3), 177-181. https://doi.org/10.5539/ass.v9n3p177

Fanzo, J. C. (2017). Decisive decisions on production compared with market strategies to improve diets in rural Africa. The Journal of Nutrition, 147(1), 1-2. https://doi.org/10.3945/jn.116.241703

FAO. (2014). The state of food and agriculture: Innovation in family farming. http://www.fao. org/3/a-i4040e.pdf

Ferro-Luzzi, A., Petracchi, C., Kuriyan, R., \& Kurpad, A. V. (1997). Basal metabolism of weight-stable chronically undernourished men and women: lack of metabolic adaptation and ethnic differences. The American Journal of Clinical Nutrition, 66(5), 1086-1093. https://doi. org/10.1093/ajen/66.5.1086

Freeman, H. E., Klein, R. E., Townsend, J. W., \& Lechtig, A. (1980). Nutrition and cognitive development among rural Guatemalan children. American Journal of Public Health, 70(12), 12771285. https://doi.org/10.2105/AJPH.70.12.1277 
Gersovitz, M., Motil, K., Munro, H. N., Scrimshaw, N. S., \& Young, V. R. (1982). Human protein requirements: assessment of the adequacy of the current recommended dietary allowance for dietary protein in elderly men and women. The American Journal of Clinical Nutrition, 35(1), 6-14. https://doi.org/10.1093/ajen/35.1.6

Glewwe, P., Jacoby, H. G., \& King, E. M. (2001). Early childhood nutrition and academic achievement: A longitudinal analysis. Journal of Public Economics, 81(3), 345-368. https://doi. org/10.1016/S0047-2727(00)00118-3

Goettler, A., Grosse, A., \& Sonntag, D. (2017). Productivity loss due to overweight and obesity: A systematic review of indirect costs. British Medical Journal Open, 7(10), 1-9. http://dx.doi. org/10.1136/bmjopen-2016-014632

Haddad, L. J., \& Bouis, H. E. (1991). The impact of nutritional status on agricultural productivity: Wage evidence from the Philippines. Oxford Bulletin of Economics and Statistics, 53(1), 4568. https://doi.org/10.1111/j.1468-0084.1991. mp53001004.x

Harris, J. (2014). Gender implications of poor nutrition and health in agricultural households. In Gender in agriculture (pp. 267-283). Springer. https://doi.org/10.1007/978-94-017-8616-4_11

Hu, Z., \& Wang, Z. (2019). Nutrition, labor supply, and productivity: Evidence from Ramadan in Indonesia [Unpublished manuscript]. Department of Economics, Cornell University. https://dx.doi.org/10.2139/ssrn.3450834

Hunsucker, S. C. (2016). Effects of obesity on united states farmers: A pilot study [Doctoral dissertation, University of Kentucky]. https:// uknowledge.uky.edu/nursing_etds/22/

Irvine, S. L., Hummelen, R., \& Hekmat, S. (2011). Probiotic yogurt consumption may improve gastrointestinal symptoms, productivity, and nutritional intake of people living with human immunodeficiency virus in Mwanza,
Tanzania. Nutrition Research, 31(12), 875-881. https://doi.org/10.1016/j.nutres.2011.10.005

Kedir, A. M. (2009). Health and productivity: Panel data evidence from Ethiopia. African Development Review, 21(1), 59-72. https:/doi. org/10.1111/j.1467-8268.2009.00203.x

Kornginnaya, S. (2013). Financial and decisionmaking participation of marginalized small farmers through the Pragathi Bandhu model in India. In Sharing Ownership, Profits, and Decision-Making in the 21st Century (pp. 217258). Emerald Group Publishing Limited. https:// doi.org/10.1108/S0885-3339(2013)0000014010

Kraut, H. A., \& Muller, E. A. (1946). Calorie intake and industrial output. Science, 104(2709), 495-497. http://dx.doi.org/10.1126/science.104.2709.495

LaFave, D., \& Thomas, D. (2016). Farms, families, and markets: New evidence on completeness of markets in agricultural settings. Econometrica, 84(5), 1917-1960. https://doi.org/10.3982/ECTA12987

Linaker, C. H., D’Angelo, S., Syddall, H. E., Harris, E. C., Cooper, C., \& Walker-Bone, K. (2020). Body mass index (BMI) and work ability in older workers: Results from the health and employment after fifty (HEAF) prospective cohort study. International Journal of Environmental Research and Public Health, 17(5), 1-13. https://doi.org/10.3390/ ijerph17051647

Linh, V. H. (2012). Efficiency of rice farming households in Vietnam. International Journal of Development Issues, 11(1), 60-73. https://doi. org/10.1108/14468951211213868

Little, M., Humphries, S., Patel, K., \& Dewey, C. (2016). Factors associated with BMI, underweight, overweight, and obesity among adults in a population of rural south India: A cross-sectional study. BMC obesity, 3(1), 1-13. https://doi.org/10.1186/s40608-016-0091-7 
Lo, Y. T., Chang, Y. H., Lee, M. S., \& Wahlqvist, M. L. (2009). Health and nutrition economics: Diet costs are associated with diet quality. Asia Pacific Journal of Clinical Nutrition, 18(4), 598-604.

Malaysian Food Composition Database. (2020). Malaysian food composition database programme c/o Institute for Medical Research Kuala Lumpur 1997 - 2015. http://myfcd.moh. gov.my/myfcdcurrent/

Marliyati, S. A., Yunieswati, W., \& Setiawan, B. (2018). Relationship between nutritional status, health status, food consumption, and lifestyle to work productivity of cocoa farmer. In Proceedings of the International Conference on Public Health (Vol. 4, No. 1, pp. 33-39). The International Institute of Knowledge Management, Private, Limited. https://doi. org/10.17501/24246735.2018.4104

Millward, D. J. (2017). Nutrition, infection and stunting: The roles of deficiencies of individual nutrients and foods, and of inflammation, as determinants of reduced linear growth of children. Nutrition Research Reviews, 30(1), 5072. https://doi.org/10.1017/S0954422416000238

Montiflor, M. O., Batt, P. J., \& Murray-Prior, R. (2008). Socio-economic impact of cluster farming for smallholder farmers in Southern Philippines. In International Symposium on the Socio-Economic Impact of Modern Vegetable Production Technology in Tropical Asia 809 (pp. 193-200). https://doi.org/10.17660/ ActaHortic.2009.809.19

Mozaffarian, D. (2016). Dietary and policy priorities for cardiovascular disease, diabetes, and obesity: A comprehensive review. Circulation, 133(2), 187-225. https://doi.org/10.1161/ CIRCULATIONAHA.115.018585

Myrskylä, M., \& Chang, V. W. (2009). Weight change, initial BMI, and mortality among middle-and older-aged adults. Epidemiology,
20(6), 840-848. http://dx.doi.org/10.1097/ EDE.0b013e3181b5f520

Ogbuoji, O., Vollmer, S., Jamison, D. T., Dickson, E. A., \& Bärnighausen, T. (2020). Economic consequences of better health: Insights from clinical data. British Medical Journal, 370. https://doi.org/10.1136/bmj.m2186

Owen, L., \& Corfe, B. (2017). The role of diet and nutrition on mental health and wellbeing. Proceedings of the Nutrition Society, 76(4), 425-426. https://doi.org/10.1017/ S0029665117001057

Pagan, R., de Haro, C. O., \& Sánchez, C. R. (2016). Obesity, job satisfaction and disability at older ages in Europe. Economics \& Human Biology, 20, 42-54. https://doi.org/10.1016/j. ehb.2015.10.001

Payette, H., Boutier, V., Coulombe, C., \& GrayDonald, K. (2002). Benefits of nutritional supplementation in free-living, frail, undernourished elderly people: A prospective randomized community trial. Journal of the American Dietetic Association, 102(8), 1088-1095. https://doi.org/10.1016/S00028223(02)90245-2

Pickett, W., King, N., Lawson, J., Dosman, J. A., Trask, C., Brison, R. J., Hagel, L., Janssen, I., \& Saskatchewan Farm Injury Cohort Study Team. (2015). Farmers, mechanized work, and links to obesity. Preventive Medicine, 70, 59-63. https:// doi.org/10.1016/j.ypmed.2014.11.012

Piper, B. (2014). A production function examination of the aggregate effects of nutrition. Journal of Macroeconomics, 40, 293-307. https://doi. org/10.1016/j.jmacro.2014.01.007

Popkin, B. M. (1978). Nutrition and labor productivity. Social Science \& Medicine. Part C: Medical Economics, 12(1-2), 117-125. https:// doi.org/10.1016/j.jmacro.2014.01.007 
Powell, B., Thilsted, S. H., Ickowitz, A., Termote, C., Sunderland, T., \& Herforth, A. (2015). Improving diets with wild and cultivated biodiversity from across the landscape. Food Security, 7(3), 535554. https://doi.org/10.1007/s12571-015-0466-5

Quaye, W. (2008). Food security situation in northern Ghana, coping strategies and related constraints. African Journal of Agricultural Research, 3(5), 334-342.

Rigg, J., Salamanca, A., Phongsiri, M., \& Sripun, M. (2018). More farmers, less farming? Understanding the truncated agrarian transition in Thailand. World Development, 107, 327-337. https://doi.org/10.1016/j.worlddev.2018.03.008

Robinson, E., Harris, E., Thomas, J., Aveyard, P., \& Higgs, S. (2013). Reducing high calorie snack food in young adults: A role for social norms and health based messages. International Journal of Behavioral Nutrition and Physical Activity, 10(1), 73. https://doi.org/10.1186/14795868-10-73

Saka, J. O., \& Lawal, B. O. (2009). Determinants of adoption and productivity of improved rice varieties in southwestern Nigeria. African Journal of Biotechnology, 8(19), 4923-4932.

Schofield, H. (2014). The economic costs of low caloric intake: Evidence from India [Unpublished manuscript]. Department of Medical Ethics and Health Policy, University of Pennsylvania. http://med.stanford.edu/content/dam/sm/hsr/ documents/H Schofield-paper.pdf.

Senkal, M., Dormann, A., Stehle, P., Shang, E., \& Suchner, U. (2002). Survey on structure and performance of nutrition-support teams in Germany. Clinical Nutrition, 21(4), 329-335. https://doi.org/10.1054/clnu.2002.0551

Sekaran, U., \& Bougie, R. (2010). Research methods for business: A skill building approach (5th ed.). John Willey \& Sons Ltd.

Sibhatu, K. T., Krishna, V. V., \& Qaim, M. (2015). Production diversity and dietary diversity in smallholder farm households. Proceedings of the National Academy of Sciences, 112(34), 1065710662. https://doi.org/10.1073/pnas.1510982112

Sibhatu, K. T., \& Qaim, M. (2018). Meta-analysis of the association between production diversity, diets, and nutrition in smallholder farm households. Food Policy, 77, 1-18. https:/doi. org/10.1016/j.foodpol.2018.04.013

Singh, I., Squire, L., \& Strauss, J. (1986). Agricultural household models: Extensions, applications, and policy. The World Bank.

Spurr, G. B. (1983). Nutritional status and physical work capacity. American Journal of Physical Anthropology, 26(S1), 1-35. https://doi. org/10.1002/ajpa.1330260503

Strauss, J. (1986). Does better nutrition raise farm productivity? Journal of Political Economy, 94(2), 297-320. https://doi. org/10.1086/261375

Strauss, J., \& Thomas, D. (1998). Health, nutrition, and economic development. Journal of economic literature, 36(2), 766-817. https://www.jstor.org/ stable/2565122

Sullivan, D. H., Patch, G. A., Walls, R. C., \& Lipschitz, D. A. (1990). Impact of nutrition status on morbidity and mortality in a select population of geriatric rehabilitation patients. The American Journal of Clinical Nutrition, 51(5), 749-758. https://doi.org/10.1093/ajen/51.5.749

Ulimwengu, J. M. (2009). Farmers' health and agricultural productivity in rural Ethiopia. African Journal of Agricultural and Resource Economics, 3(2), 83-100. https://doi. org/10.22004/ag.econ.56902

Terano, R., \& Mohamed, Z. (2014). Life satisfaction among farmers in paddy granaries in Malaysia. Asian Social Science, 10(2), 229-235. https://doi.org/10.5539/ass.v10n2p229

Tiwasing, P., Dawson, P., \& Garrod, G. (2019). The relationship between micronutrient intake 
and labour productivity: Evidence from ricefarming households in Thailand. Outlook on Agriculture, 48(1), 58-65. https://doi. org/10.1177/0030727019829080

Wadud, A., \& White, B. (2000). Farm household efficiency in Bangladesh: A comparison of stochastic frontier and DEA methods. Applied Economics, 32(13), 1665-1673. https://doi. org/10.1080/000368400421011

Weiss, A. J., Fingar, K. R., Barrett, M. L., Elixhauser, A., Steiner, C. A., Guenter, P., \& Brown, M. H. (2016). Characteristics of hospital stays involving malnutrition, 2013: Statistical brief\# 210. Agency for Healthcare Research and Quality. https://www.hcup-us.ahrq.gov/ reports/statbriefs/sb210-Malnutrition-HospitalStays-2013.jsp

Wiggins, S., \& Keats, S. (2013, March 20). Smallholder agriculture's contribution to better nutrition. https://cdn.odi.org/media/documents/8376.pdf
Wolgemuth, J. C., Latham, M. C., Hall, A., Chesher, A., \& Crompton, D. W. (1982). Worker productivity and the nutritional status of Kenyan road construction laborers. The American Journal of Clinical Nutrition, 36(1), 68-78. https://doi. org/10.1093/ajen/36.1.68

World Health Organization. (2000). Obesity: Preventing and managing the global epidemic (No. 894). Great Neck Publishing. https://books. google.com.my/books?hl=en\&lr=\&id=AvnqOsq v9doC\&oi $=$ fnd\&pg $=$ PA1\&ots $=6 \mathrm{WF} 0 \mathrm{brXX} 4 \mathrm{~N} \&$ sig=PTi3E_B2FlfS2CkxlFQfU5s4fBU\&redir_ $\mathrm{esc}=\mathrm{y} \# \mathrm{v}=$ onepage $\& \mathrm{q} \& \mathrm{f}=$ false

Yu, H. H., Nam, J. E., \& Kim, I. S. (2003). A study of the nutritional intake and health condition of female college students as related to their frequency of eating breakfast. Korean Journal of Community Nutrition, 8(6), 964-976. 


\section{APPENDIX}

\section{Appendix A}

Table 8

Key variables used in main analysis

\begin{tabular}{ll}
\hline \multicolumn{1}{c}{ Variables } & Definition \\
\hline Productivity & $\begin{array}{l}\text { By following Cobb and Douglas (1928) theory of production, the weighted sum of } \\
\text { paddy inventory, machinery, total cultivated land, hours worked and hired labour are } \\
\text { divided by the weighted sum of paddy production to acquire productivity value. }\end{array}$ \\
\hline Nutrition & $\begin{array}{l}\text { Obtaining the current nutritional status of calorie to productivity follows Strauss } \\
(1986) \text { paper. Individual's total caloric intake (kcal) per day. The total household } \\
\text { calorie consumption from the 30-day recall was then divided by 30 to obtain a calorie } \\
\text { value per day. }\end{array}$ \\
\hline Health Status & $\begin{array}{l}\text { Expressed as Body Mass Index (BMI) and measured as weight in kilograms divided } \\
\text { by height in meters squared (kg/m²) (Ulimwengu, 2009). }\end{array}$ \\
\hline Family Labour & The family members that are in the household \\
\hline Hired Labour & Non-family member which are acquired for farm production \\
\hline Capital & Total monthly earnings from farm production (rm) \\
\hline Land & Cultivated area (ha) \\
\hline Age & Age of household head (years) \\
\hline
\end{tabular}

